\title{
EKSEKUTABILITAS PUTUSAN MAHKAMAH AGUNG TERHADAP PENCALONAN ANGGOTA DEWAN PERWAKILAN DAERAH
}

Kajian Putusan Nomor 65P/HUM/2018

\section{EXECUTABILITY OF SUPREME COURT DECISION ON ELECTION OF THE REGIONAL REPRESENTATIVE COUNCIL MEMBERS}

An Analysis of Decision Number 65P/HUM/2018

\author{
Tahegga Primananda Alfath \\ Fakultas Hukum Universitas Narotama Surabaya \\ Jl. Arief Rahman Hakim No. 51 Surabaya 60117 \\ Email: tahegga.primananda@narotama.ac.id
}

Naskah diterima: 4 Desember 2018; revisi: 6 Desember 2019; disetujui 26 Desember 2019

http://dx.doi.org/10.29123/jy.v12i3.357

\begin{abstract}
ABSTRAK
Komisi Pemilihan Umum (KPU) membuat Peraturan KPU Nomor 26 Tahun 2018 tentang Perubahan Kedua Atas Peraturan KPU Nomor 14 Tahun 2018 tentang Pencalonan Perseorangan Pemilu Anggota Dewan Perwakilan Daerah yang khususnya diatur dalam Pasal 60A. Akan tetapi ketentuan pada peraturan tersebut diputus telah bertentangan dengan Undang-Undang Nomor 12 Tahun 2011 tentang Pembentukan Peraturan Perundang-undangan, dan tidak boleh dimaknai berlaku surut oleh Mahkamah Agung dalam Putusan Nomor 65P/ HUM/2018. Atas adanya fakta hukum yang tidak koheren tersebut, diambil isu hukum terkait kepastian hukum dapat atau tidaknya calon anggota Dewan Perwakilan Daerah yang juga merupakan pengurus (fungsionaris) partai. Penelitian ini menggunakan metode penelitian hukum dengan pendekatan perundang-undangan, pendekatan konseptual, dan pendekatan kasus. Hasil dari penelitian ini, pertama, terdapat kesesatan dalam penalaran hukum pada ratio decidendi Putusan Nomor 65P/HUM/2018. Kedua, putusan Mahkamah Agung tersebut dapat disimpangi oleh KPU, karena sebagaimana dalam kewenangan Mahkamah Konstitusi melakukan
\end{abstract}

pengujian konstitusionalitas terhadap undang-undang yang bersifat erga omnes.

Kata kunci: racio decidendi; penalaran hukum; Dewan Perwakilan Daerah.

\section{ABSTRACT}

The General Election Commission (KPU) has enacted KPU Regulation Number 26 of 2018 concerning the Second Amendment to KPU Regulation Number 14 of 2018 over the Nomination of Individual Election of Regional Representative Council Members. The provisions of this regulation, especially Article 60A, contravene with Law Number 12 of 2011 concerning the Legislation Drafting Process. In the Decision Number 65P/HUM/2018, the Supreme Court should not retroactively interpret the KPU regulation. Due to the incoherent legal facts, legal issues raised in this article is about legal certainty whether a candidate of the Regional Representative Council (DPD) member can also become a political party official. This research uses legal research methods with normative, conceptual, and case approaches. The results of this research are 
as follows. The results of this research are as follows. First, there are errors in legal reasoning on the ratio decidendi of the Supreme Court Decision Number 65P/ HUM/2018. Second, the Supreme Court Decision can be distorted by the KPU because the court acted like the Constitutional Court reviewing an erga omnes law.

Keywords: racio decidendi; legal reasoning; Regional Representative Council.
I. PENDAHULUAN

\section{A. Latar Belakang}

Putusan Nomor 65P/HUM/2018 yang merupakan jawaban atas judicial review terhadap Peraturan Komisi Pemilihan Umum (KPU) Nomor 26 Tahun 2018 tentang Perubahan Kedua Atas Peraturan KPU Nomor 14 Tahun 2018 tentang Pencalonan Perseorangan Pemilu Anggota Dewan Perwakilan Daerah, memunculkan sebuah kontroversi di masyarakat. Putusan tersebut banyak dinilai orang berlainan sikap dengan Putusan Mahkamah Konstitusi Nomor 30/PUU-XVI/2018.

Putusan Mahkamah Konstitusi Nomor 30/PUU-XVI/2018 merupakan putusan atas judicial review terhadap Pasal 182 huruf 1 Undang-Undang Nomor 7 Tahun 2017 tentang Pemilihan Umum (UU Nomor 7 Tahun 2017), yang dinyatakan tidak memiliki kekuatan hukum yang mengikat secara bersyarat, sepanjang frasa "pekerjaan lain" tidak dimaknai mencakup pula pengurus (fungsionaris) partai politik.

KPU merespons putusan Mahkamah Konstitusi tersebut dengan melakukan perubahan terhadap Peraturan KPU Nomor 14 Tahun 2018 tentang Pencalonan Perseorangan Pemilu Anggota Dewan Perwakilan Daerah, dan lahirlah Peraturan KPU Nomor 26 Tahun 2018. Hal tersebut diperlihatkan dalam konsiderannya, yang dapat diartikan bahwa Putusan Mahkamah Konstitusi Nomor 30/PUU-XVI/2018 adalah ratio legis dalam pembentukan Peraturan KPU
Nomor 26 Tahun 2018.

Pasal 60A Peraturan KPU Nomor 26 Tahun 2018 menjadi salah satu objek gugatan judicial review kepada Mahkamah Agung oleh pemohon, seorang calon anggota Dewan Perwakilan Daerah Republik Indonesia (DPD), yang mana juga salah seorang pengurus (fungsionaris) partai politik. Pemohon beralasan pasal tersebut dapat merugikan dan berpotensi membatasi hak-hak konstitusi pemohon sebagai calon anggota DPD.

Pemohon juga mendalihkan bahwa Peraturan KPU Nomor 26 Tahun 2018 tidak sesuai dengan ketentuan Pasal 75 ayat (2) UU Nomor 7 Tahun 2017, bahwa Peraturan KPU merupakan pelaksanaan peraturan perundangundangan. Hal ini berarti bahwa Peraturan KPU tidak boleh bertentangan dengan peraturan perundang-undangan. Selain itu, pemohon juga mendalihkan bahwa Putusan Mahkamah Konstitusi Nomor 30/PUU-XVI/2018 tidak dapat berlaku surut ke belakang. Hal tersebut didasarkan atas Pasal 28 huruf i UUD NRI 1945 jo. Pasal 7 Undang-Undang Nomor 24 Tahun 2003 tentang Mahkamah Konstitusi (UU Nomor 24 Tahun 2003). Putusan Mahkamah Konstitusi tersebut juga dinilai oleh pemohon tidak dapat dijadikan sebagai dasar penyusunan/pembuatan Peraturan KPU Nomor 26 Tahun 2018.

Pasal 10 ayat (1) huruf d jo. Pasal 10 ayat (2) Undang-Undang Nomor 12 Tahun 2011 tentang Pembentukan Peraturan Perundang-undangan (UU Nomor 12 Tahun 2011) menyatakan, bahwa 
putusan Mahkamah Konstitusi merupakan salah satu muatan materi yang harus ditindaklanjuti oleh Dewan Perwakilan Rakyat (DPR) atau Presiden. Terlebih Peraturan KPU merupakan jenis peraturan perundang-undangan yang tidak termasuk dalam Pasal 7 UU Nomor 12 Tahun 2011.

Mahkamah Agung dalam amar Putusan Nomor 65P/HUM/2018 mengabulkan sebagian permohonan pemohon. Adapun perihal yang dikabulkan adalah pertama, Pasal 60A Peraturan KPU Nomor 26 Tahun 2018 bertentangan dengan Pasal 5 huruf d dan Pasal 6 ayat (1) huruf I UU Nomor 12 Tahun 2011. Kedua, menyatakan bahwa Peraturan KPU Nomor 26 Tahun 2018 tetap mempunyai kekuatan hukum yang mengikat dan berlaku umum sepanjang tidak diberlakukan surut terhadap peserta pemilihan umum (pemilu) anggota DPD tahun 2019 yang telah mengikuti tahapan, program, dan jadwal penyelenggaraan pemilu tahun 2019 berdasarkan Peraturan KPU Nomor 7 Tahun 2017.

Isu hukum yang muncul pasca Putusan Nomor 65P/HUM/2018 adalah putusan tersebut seolahmeniadakankedudukanPutusanMahkamah Konstitusi Nomor 30/PUU-XVI/2018. Putusan Mahkamah Konstutusi pada dasarnya memiliki sifat declaratoir dan constitutief. Dalam perkara pengujian undang-undang yang menyatakan bahwa putusan mengabulkan, hal tersebut berarti dimaknai sebagai apa yang menjadi hukum dari suatu norma undang-undang adalah bertentangan dengan UUD NRI 1945 (declaratoir). Pada saat yang bersamaan hal tersebut berarti meniadakan keadaan hukum berdasarkan norma yang dibatalkan dan menciptakan norma yang baru (constitutief) (Sambuari, 2013:20).

Putusan Mahkamah Konstitusi sebagaimana diatur dalam Pasal 24C UUD NRI 1945 bersifat final, maka putusan tersebut sejak dibacakan mengikat bagi seluruh komponen bangsa, bagi penyelenggara negara (pemerintah) maupun warga negara. Putusan Mahkamah Konstitusi tersebut sudah semestinya dilaksanakan oleh semua pihak.

Menurut Syafa'at, putusan Mahkamah Konstitusi memiliki dua karakteristik, ada putusan yang dapat dilaksanakan langsung tanpa harus dibuat peraturan baru atau perubahan, ada pula yang memerlukan pengaturan lebih lanjut terlebih dahulu. Pertama, putusan Mahkamah Konstitusi yang langsung dapat dilaksanakan adalah putusan membatalkan norma tertentu yang tidak menganggu sistem norma yang ada dan tidak memerlukan pengaturan lebih lanjut. Kedua, putusan Mahkamah Konstitusi yang untuk pelaksanaannya membutuhkan aturan lebih lanjut, yaitu putusan membatalkan suatu norma yang memengaruhi norma-norma lain, atau untuk melaksanakannya diperlukan aturan yang lebih operasional (Syafa'at, 2018:2).

Penelitian ini akan membahas secara komprehensif tentang dasar pertimbangan hukum hakim dalam Putusan Nomor 65P/HUM/2018, dalam hal ini apakah hakim agung menyimpangi Putusan Mahkamah Konstitusi Nomor 30/PUUXVI/2018, ataukah justru menguatkan. Serta menganalisis implikasi Putusan Mahkamah Konstitusi Nomor 30/PUU-XVI/2018 dengan dijadikannya sebagai ratio legis Peraturan KPU Nomor 26 Tahun 2018 apakah telah sesuai dengan konsep pembentukan peraturan perundangundangan.

\section{B. Rumusan Masalah}

Berangkat dari identifikasi permasalahan yang telah dilakukan sebelumnya, penelitian ini mengambil rumusan masalah sebagai berikut: 
1. Apakah ratio decidendi hakim fakta, dan proposisi hukum (Weruin, 2017:380agung dalam Putusan Nomor 65P/ 382).

$\mathrm{HUM} / 2018$ telah sesuai dengan penalaran hukum?

2. Apakah Putusan Nomor 65P/ HUM/2018 dapat disimpangi oleh Komisi Pemilihan Umum?

\section{Tujuan dan Kegunaan}

Tujuan dari penelitian ini, adalah:

1. Untuk menganalisis kesesuaian ratio decidendi hakim agung dalam Putusan Nomor 65P/HUM/2018 dengan penalaran hukum.

2. Untuk menganalisis Putusan Nomor 65P/HUM/2018 dapatkah disimpangi oleh Komisi Pemilihan Umum.

Manfaat yang dapat dipetik dari hasil penelitian ini adalah pertama, menambah khasanah keilmuan hukum khususnya mengenai penafsiran hakim, dan kedudukan putusan Mahkamah Konstitusi sebagai dasar hukum. Kedua, menjadi cara pandang baru bagi penegak hukum dalam menangani isu hukum yang serupa.

\section{Tinjauan Pustaka}

\section{Konsep Penalaran Hukum}

Penalaran hukum bagi setiap sarjana hukum merupakan ars (keahlian), yang menunjukkan sui generis dari keahlian yang lain. Hakim dalam memeriksa dan memutus perkara harus senantiasa membekali dirinya dengan pemahaman ilmu hukum yang luas, (Mas, 2012:288). Salah satunya adalah ilmu mengenai penalaran hukum. Penalaran hukum adalah penerapan logika berpikir dalam memahami prinsip, aturan, data,

Penalaran hukum biasa juga disebut dengan legal reasoning, di mana dalam negara yang menganut sistem common law, didasarkan oleh dua hal yaitu: pertama, reasoning based on precedent. Bahwa penalaran ini menggunakan preseden sebagai landasan dengan melakukan identifikasi terhadap ratio decidendi hakim dalam memutuskan suatu perkara dalam pengadilan yang telah memiliki putusan yang berkuatan hukum. Kedua, reasoning based on rules. Bahwa yang menjadi titik tolak untuk melakukan identifikasi adalah aturan atau peraturan perundang-undangan (Hadjon \& Djatmiati, 2014:36-37).

Dalam sebuah metode penelitian hukum, hal tersebut dapat diterjemahkan dalam pendekatan penelitian yang digunakan. Jika penelitian itu menggunakan pendekatan dengan meneliti kasus yang telah diputuskan oleh hakim, maka ini yang kemudian dinamakan dengan pendekatan kasus (case approach). Sedangkan jika pendekatan yang dilakukan merupakan pendekatan berdasarkan peraturan perundang-undangan, maka penelitian tersebut menggunakan pendekatan peraturan perundang-undangan (state approach).

Penalaran hukum dapat dilakukan dengan dua model, yaitu induksi dan deduksi. Agar kedua penalaran tersebut valid, maka aturanaturan (hukum) dan penyimpulan dari kedua model tersebut harus diperhatikan. Jika terjadi kesalahan dalam menyimpulkan itu, berarti ada kesesatan dalam bernalar (fallacy). Ada lima model kesesatan bernalar hukum, yaitu:

a. Argumentum ad ignorantiam, dalam bidang hukum hal ini dilakukan misalnya hakim dalam perkara tata usaha negara menggunakan hukum 
acara perdata, khususnya mengenai pembuktian.

b. Argumentum ad verecundiam, bahwa kesimpulan yang diambil berdasarkan orang yang mengemukakannya adalah orang yang berwibawa, berkuasa, ahli. Akan tetapi dalam bidang hukum hal tersebut dapat dibenarkan jika berkaitan dengan yurisprudensi.

c. Argumentum ad hominem, penalaran yang digunakan dilandasi atas keadaan orangnya.

d. Argumentum ad misericordiam, penalaran yang memiliki tujuan untuk menimbulkan belas kasihan. Dalam hukum dapat dibenarkan ketika meminta keringanan hukum.

e. Argumentum ad baculum, penalaran yang dibangun dilandasi atas keadaan yang terancam (dalam ancaman).

\section{Teori tentang Putusan Hakim}

Putusan hakim merupakan salah satu dari hukum negara, sebagaimana Ashiddiqie mengatakan bahwa hukum negara adalah hukum yang ditetapkan dengan keputusan kekuasaan negara sebagai hasil dari tindakan pengaturan, penetapan, atau pengadilan. Lebih lanjut dinyatakan bahwa putusan itu adalah hasil dari penghakiman pengadilan (Asshiddiqie, 2010:78). Maka dapat disimpulkan bahwa putusan hakim merupakan pernyataan hakim, sebagai pejabat yang berwenang dalam lingkup kekuasaan kehakiman atau pengadilan, yang dibuat dalam bentuk tertulis, dan diucapkan dalam sidang pengadilan yang terbuka untuk umum dengan tujuan untuk menyelesaikan suatu perkara.
Tentang pengertian hakim, merujuk pada ketentuan yang terdapat dalam Pasal 2 angka 5 UU Nomor 48 Tahun 2009, bahwa yang dimaksud dengan hakim adalah hakim pada Mahkamah Agung dan hakim pada badan peradilan yang berada di bawahnya dalam lingkungan peradilan umum, lingkungan peradilan agama, lingkungan peradilan militer, lingkungan peradilan tata usaha negara, dan hakim pada pengadilan khusus yang berada dalam lingkungan peradilan tersebut. Hakim pada Mahkamah Agung yang kemudian disebut sebagai Hakim Agung, dan ada pula hakim pada Mahkamah Konstitusi disebut sebagai Hakim Mahkamah Konstitusi.

Hakim dalam mengeluarkan putusan memiliki beberapa kaidah sebagaimana diatur dalam UU Nomor 48 Tahun 2009, yaitu: pertama, putusan pengadilan hanya sah dan mempunyai kekuatan hukum apabila diucapkan dalam sidang terbuka untuk umum. Keterbukaan ini tidak terkecuali terhadap pemeriksaan yang dilakukan pada sidang tertutup. Hal ini menunjukkan adanya prinsip keterbukaan yang harus dianut oleh pengadilan, khususnya hakim dalam mengeluarkan putusan.

Kedua, seorang hakim atau panitera wajib mengundurkan diri dari persidangan apabila mempunyai kepentingan langsung atau tidak langsung dengan perkara yang sedang diperiksa, baik atas kehendaknya sendiri maupun atas permintaan pihak yang berperkara. Ada sanksi apabila seorang hakim atau panitera memiliki konflik interest dengan para pihak yang bersengketa, yaitu putusan dinyatakan tidak sah, dan terhadap hakim atau panitera yang bersangkutan dikenakan sanksi administratif atau dipidana sesuai dengan ketentuan peraturan perundang-undangan. 
3. Konsep Pengujian Undang-Undang (Judicial Review) oleh Mahkamah Konstitusi

Pengujian undang-undang (judicial review) adalah memandang, menilai atau menguji kembali produk hukum yang berupa peraturan perundangundangan sebagai bentuk pengawasan kekuasaan kehakiman agar peraturan perundang-undangan tersebut tidak bertentangan dengan aturan yang ada di atasnya. Hal tersebut juga untuk menjamin adanya kepastian hukum. Radbruch menjelaskan bahwa kepastian hukum dapat diperoleh jika terpenuhi empat kategori, yaitu: pertama, bahwa hukum itu harus berbentuk positif, dalam hal ini adalah jelas normanya. Kedua, didasarkan atas terjadinya suatu fakta hukum. Ketiga, fakta hukum dijelaskan secara jelas dan tidak menimbulkan bias makna. Keempat, hukum positif yang dibuat tidak mudah dilakukan perubahan (Sulardi \& Wardoyo, 2015:263).

Kekuasaan kehakiman yang diberikan kewenangan dalam melakukan judicial review di Indonesia ada Mahkamah Konstitusi dan Mahkamah Agung. Kewenangan Mahkamah Konstitusi dalam melakukan judicial review sebagaimana dimaksud dalam Pasal 24C UUD NRI 1945 adalah melakukan pengujian undangundang terhadap UUD NRI 1945. Sedangkan kewenangan Mahkamah Agung dalam melakukan judicial review adalah berkaitan dengan peraturan di bawah undang-undang terhadap undangundang.

Kewenangan ini memberikan suatu gambaran bahwa judicial review yang dilakukan oleh kekuasaan kehakiman merupakan negative legislature, bukan positive legislature. Sebagaimana pendapat dari Mahfud MD, bahwa positive legislature dipahami sebagai wilayah legislator (pembuat undang-undang) (Martitah, 2013:xiii). Marzuki (2007:6) memberikan penegasan bahwa constitutional court (dalam hal ini adalah Mahkamah Konstitusi) juga memiliki kewenangan legislature sebagai mana kekuasaan legislatif, walaupun kewenangannya hanya berupa negative legislature.

Isra menyatakan bahwa kontrol yang berupa judicial review oleh kekuasaan kehakiman (lembaga yudisial) merupakan suatu keniscayaan, hal tersebut dijadikan sebagai sarana purifikasi undang-undang yang dihasilkan oleh lembaga legislatif. Tanpa kontrol dari lembaga yudisial sangat terbuka kemungkinan undang-undang akan merugikan rakyat (Isra, 2010). Maka hal ini sudah semestinya bahwa setiap putusan yang dikeluarkan oleh lembaga yudisial (khususnya Mahkamah Konstitusi) harus dipatuhi oleh semua pihak, karena putusan terkait judicial review adalah bentuk dari kepastian hukum atas keterjaminan aspirasi fundamental rakyat.

\section{Konsep Perlembagaan Parlemen}

Istilah tentang parlemen dan legislatif, memiliki kesamaan dalam tugas dan fungsinya dalam kenegaraan. Kata parlemen berasal dari bahasa latin parliamentum, yang berarti berbicara, dan dapat diartikan bahwa parlemen adalah tempat atau badan yang dijadikan sebagai wadah berbicara para wakil rakyat satu sama lain, untuk membicarakan hal-hal penting tentang rakyat (Safa'at, 2010:24).

Secara umum ada tiga prinsip perwakilan yang dikenal di dunia. Pertama, representasi politik (political representation), yaitu perwakilan melalui prosedur partai politik sebagai salah satu pilar demokrasi modern. Kedua, representasi teritorial (territorial representation) 
yang merupakan perwakilan daerah. Dan ketiga, representasi fungsional (functional representation) yaitu mencerminkan keterwakilan fungsional, misalkan di Inggris adalah kelompokkelompok tuan tanah dan para bangsawan Inggris yang dulunya berkuasa mutlak, yang selanjutnya ditampung kepentingannya dalam wadah House of Lord (Asshiddiqie, 2007:154).

Pembentukan Dewan Perwakilan Daerah Republik Indonesia (DPD) dimulai dari keberadaan amandemen ketiga dan keempat UUD NRI 1945 Pasal 22C, 22D, dan 22E yang merupakan dasar pembentukan lembaga yang secara fungsi diharapkan dapat menjadi representasi kepentingan daerah. DPD mencerminkan keterwakilan politik daerah di tingkat pusat, dengan keanggotaannya masingmasing empat orang keterwakilan dari setiap provinsi di seluruh Indonesia yang dipilih secara langsung dalam agenda pemilihan umum setiap lima tahun sekali.

DPD diadakan untuk tiga alasan mendasar mengakomodasi keberadaan DPD dalam struktur ketatanegaraan Indonesia, yaitu:

1) Memperkuat ikatan daerah-daerah dalam wadah Negara Kesatuan Republik Indonesia;

2) Meningkatkan agregasi dan akomodasi aspirasi dan kepentingan daerah-daerah dalam perumusan kebijakan nasional berkaitan dengan negara dan daerah-daerah;

3) Mendorong percepatan demokrasi pembangunan dan kemajuan daerah secara serasi dan seimbang (Sirajuddin \& Winardi, 2015:118119).

Selain itu tujuan keberadaan DPD dalam ketatanegaraan pasca reformasi adalah sebagai bentuk penguatan terhadap peran perwakilan daerah dalam lembaga perwakilan di Indonesia.
Indonesia menganut sistem parlemen bikameral, yaitu sistem parlemen yang terdiri dari dua kamar atau badan. DPD dibuat sebagai double check terhadap dalam sistem bikameral (Tinambunan \& Prasetio, 2019:269). Akan tetapi peran DPD tidaklah seperti halnya senator (parlemen dari unsur perwakilan daerah) dalam kebanyakan sistem bikameral yang ada di dunia, karena menurut Strong (Safa'at, 2010:35), secara umum terdapat beberapa karakter dari sistem parlemen bikameral, yaitu:

1. Kamar kedua cenderung lebih kecil daripada kamar pertama.

2. Masa jabatan anggota kamar kedua lebih lama dibanding masa jabatan anggota kamar pertama.

3. Anggota kamar pertama dipilih secara bertahap atau bersama.

Kewenangan DPD sebagaimana diatur dalam UUD NRI 1945 mencerminkan bahwa sistem parlemen bikameral yang dianut oleh Indonesia adalah soft bicameral. Adapun keanggotaan DPD diatur dalam Pasal 252 Undang-Undang Nomor 17 Tahun 2014 tentang MPR, DPR, DPD, DPRD yang isinya dinyatakan:

1) Anggota DPD dari setiap provinsi ditetapkan sebanyak empat orang.

2) Jumlah anggota DPD tidak lebih dari 1/3 (sepertiga) jumlah anggota DPR.

3) Keanggotaan DPD diresmikan dengan Keputusan Presiden.

4) Anggota DPD dalam menjalankan tugasnya berdomisili di daerah pemilihannya dan mempunyai kantor di ibu kota provinsi daerah pemilihannya.

5) Masa jabatan anggota DPD adalah lima tahun dan berakhir pada saat 
anggotaDPDyang barumengucapkan sumpah/janji.

\section{METODE}

Metode yang digunakan adalah metode penelitian hukum. Pendekatan yang digunakan dalam penelitian ini adalah pertama, pendekatan perundang-undangan (state approach) digunakan dalam menganalisis kedudukan putusan Mahkamah Konstitusi dalam pembentukan peraturan perundang-undangan. Kedua, pendekatan konseptual (conseptual approach) digunakan dalam menganalisis teori dan konsep hukum tentang pembentukan peraturan perundang-undangan, serta perwakilan dalam DPD. Ketiga, pendekatan kasus (case approach) yaitu menganalisis kasus berdasarkan Putusan Mahkamah Agung dan Mahkamah Konstitusi terkait kepastian hukum pencalonan anggota DPD yang merupakan pengurus (fungsionaris) partai politik.

Sumber bahan hukum yang digunakan dalam penelitian ini meliputi bahan hukum primer dan bahan hukum sekunder. Bahan hukum primer meliputi UUD NRI 1945, Undang-Undang Nomor 12 Tahun 2011 tentang Pembentukan Peraturan Perundang-undangan, Undang-Undang Nomor 7 Tahun 2017 tentang Pemilihan Umum, Putusan Nomor 65P/HUM/2018, dan Putusan Mahkamah Konstitusi Nomor 30/PUU-XVI/2018. Bahan hukum sekunder meliputi seluruh penelitian hukum yang berkaitan dengan isu hukum yang diteliti baik dalam bentuk skripsi, tesis, maupun disertasi. Atau dapat juga berupa doktrin ilmu hukum yang ada dalam buku atau jurnal ilmiah hukum.

Prosedur pengumpulan data dilakukan dengan bahan hukum primer berupa peraturan perundang-undangan dan putusan pengadilan dikumpulkan dengan metode inventarisir dan kategorisasi. Bahan hukum sekunder diinventarisasi berdasarkan isu hukum yang dikaji. Bahan hukum sekunder dikumpulkan melalui penelusuran kepustakaan, yaitu pengumpulan bahan dengan melakukan penelusuran terhadap sejumlah literatur hukum, dokumen hukum, pendapat pakar hukum, serta artikel-artikel ilmiah hukum yang dapat memperjelas konsepkonsep hukum.

Metode analisis data dilakukan dengan bahan hukum primer dan bahan hukum sekunder yang telah dikumpulkan (inventarisasi), kemudian diklasifikasi dan dianalisis dengan pendekatanpendekatan yang digunakan dalam penelitian ini.

\section{HASIL DAN PEMBAHASAN}

\section{A. Kesesuaian Ratio Decidendi Hakim Mahkamah Agung dengan Penalaran Hukum dalam Putusan Nomor 65P/ HUM/2018}

Mahkamah Agung memiliki kewenangan dalam pengujian peraturan perundangundangan di bawah undang-undang terhadap peraturan perundang-undangan berdasarkan Pasal 24A UUD NRI 1945, Pasal 20 ayat (2) huruf b Undang-Undang Nomor 48 Tahun 2009 tentang Kekuasaan Kehakiman, Pasal 31 ayat (1) Undang-Undang Nomor 14 Tahun 1985 tentang Mahkamah Agung, serta Pasal 1 angka 1 Peraturan Mahkamah Agung Nomor 1 Tahun 2011 tentang Hak Uji Materiil (PERMA Nomor 1 Tahun 2011).

Objek permohonan keberatan hak uji materiel pemohon dalam Putusan Nomor 65P/ HUM/2018 adalah Peraturan KPU Nomor 26 Tahun 2018. Pemohon merasa haknya dirugikan 
dengan alasan berupa fakta hukum sebagai berikut:

1. Pemohon adalah peserta pemilu anggota DPD yang telah memenuhi syarat sebagaimana ditentukan dalam Pasal 182 jo. Pasal 183 UU Nomor 7 Tahun 2017, dan telah mendaftarkan diri sebagai bakal calon anggota DPD melalui KPU Provinsi Kalimantan Barat dengan memenuhi seluruh kelengkapan administrasi bakal calon anggota DPD.

2. Terkait kedudukan pemohon juga sebagai fungsionaris partai politik dalam melaksanakan pendaftaran sebagai calon anggota DPD telah sesuai dengan tahapan penyelenggaraan Pemilu 2019, di mana pada saat itu diatur dengan Peraturan KPU Nomor 14 Tahun 2018 tentang Pencalonan Perseorangan Peserta Pemilu Anggota DPD, yang pada saat aturan itu berlaku tidak melarang anggota partai politik untuk mendaftarkan diri sebagai calon anggota DPD.

3. Pada tahapan pendaftaran sebagai calon anggota DPD tersebut, KPU pada saat itu juga melakukan tahapan verifikasi dan saat ini telah menetapkan pemohon dalam Daftar Calon Sementara pada nomor urut 38.

4. Bahwa pada tanggal 23 Juli 2018, Mahkamah Konstitusi melalui Putusan Nomor 30/PUU-XVI/2018, menyatakan: Frasa "pekerjaan lain" dalam Pasal 182 huruf 1 UU Nomor 7 Tahun 2017 bertentangan dengan UUD NRI 1945 dan tidak mempunyai kekuatan hukum mengikat secara bersyarat sepanjang tidak dimaknai mencakup pula pengurus (fungsionaris) partai politik.

5. Bahwa menindaklanjuti putusan Mahkamah Konstitusi tersebut, KPU melakukan perubahan terhadap Peraturan KPU Nomor 14 Tahun 2018 dengan Peraturan KPU Nomor 26 Tahun 2018, dengan memasukkan Pasal 60A yang mewajibkan pengurus partai politik yang akan mencalonkan diri sebagai perseorangan peserta Pemilu DPD agar mengundurkan diri dari kedudukannya sebagai pengurus partai politik.

6. Bahwa tanggal 20 September 2018, KPU menerbitkan Daftar Calon Tetap anggota DPD, yang berkonsekuensi dicoretnya nama pemohon dari Daftar Calon Tetap.

7. Atas fakta hukum tersebut, pemohon merasa dirugikan oleh KPU karena kehilangan kesempatan untuk dapat mengikuti Pemilu DPD 2019.

Atas gugatan yang disampaikan oleh pemohon tersebut, KPU kemudian memberikan jawaban, atas alasan hukum dari tindakan hukum yang dilakukannya, yaitu sebagai berikut:

1. Kewenangan KPU dalam menyusun Peraturan KPU Nomor 26 Tahun 2018 merupakan wewenang atribusi KPU dalam penyelenggaraan pemilu khususnya terkait dengan pencalonan anggota DPD. Selain itu juga merupakan wewenang yang diatur dalam Pasal 12 huruf c, Pasal 
13 huruf b, dan Pasal 75 ayat (1) UU Nomor 7 Tahun 2017.

2. Bahwa mekanisme penyusunan Peraturan KPU Nomor 26 Tahun 2018 telah sesuai dengan ketentuan dalam Pasal 5 UU Nomor 12 Tahun 2011, yang menyatakan bahwa dalam membentuk peraturan perundangundangan yang baik berpedoman pada sumber hukum formal Indonesia, yang kemudian dimaknai KPU adalah undang-undang dan putusan hakim dalam hal ini adalah termasuk putusan Mahkamah Konstitusi. Yang mana hal tersebut juga didasarkan kepada Pasal 6 UU Nomor 12 Tahun 2011.

3. Materi muatan Peraturan KPU Nomor 26 Tahun 2018 didasarkan karena adanya Putusan Mahkamah Konstitusi Nomor 30/PUUXVI/2018. Dengan alasan hukum bahwa KPU sebagaimana ketentuan Pasal 474 ayat (4) UU Nomor 7 Tahun 2017, memiliki kewajiban untuk menindaklanjuti putusan Mahkamah Konstitusi dan guna memberikan kepastian hukum karena tahapan pemilu sedang berlangsung.

4. Penambahan Pasal 60A yang diatur dalam Peraturan KPU Nomor 26 Tahun 2018 mengatur kewajiban Bakal Calon Anggota DPD yang merupakan pengurus partai politik untuk mengundurkan diri yang disampaikan paling lambat satu hari sebelum penetapan Daftar Calon Tetap.
5. Bahwa sampai dengan waktu satu hari sebelum penetapan Daftar Calon Tetap, namun pemohon tidak menyerahkan surat pernyataan pengunduran diri sebagai pengurus partai politik. Konsekuensinya, menurut hemat KPU, tindakan pemohon tersebut telah tidak sesuai dengan ketentuan peraturan perundang-undangan dan putusan Mahkamah Konstitusi, yang mengakibatkan pemohon tidak memenuhi syarat dan namanya tidak tercantum dalam Daftar Calon Tetap Anggota DPD.

Mahkamah Agung dalam pertimbangannya mengangkat dua isu hukum yang menjadi pokok permasalahan yang akan diselesaikan. Pertama, apakah KPU memiliki kewenangan membuat Peraturan KPU Nomor 26 Tahun 2018, dengan dalih menindaklanjuti Putusan Mahkamah Konstitusi Nomor 30/PUU-XVI/2018 guna memberikan kepastian hukum karena tahapan pemilu sedang berlangsung, walaupun materi muatan yang diatur dalam putusan Mahkamah Konstitusi tersebut belum ditindaklanjuti oleh DPR dan Presiden. Kedua, apakah penerapan Peraturan KPU Nomor 26 Tahun 2018 dapat dilakukan pada tahapan pemilu anggota DPD tahun 2019 yang telah dilaksanakan dan sedang berlangsung.

Mahkamah Agung melakukan penafsiran hukum sistematis dalam mencari kewenangan KPU membuat Peraturan KPU. MahkamahAgung berpendapat bahwa KPU dalam hal membuat Peraturan KPU memang adalah kewenangan yang bersifat atribusi yang diberikan kepada KPU dari UU Nomor 7 Tahun 2017. Hal ini berarti menegaskan bahwa peraturan yang dibuat 
oleh KPU memang sebagai domain KPU sebagai lembaga negara yang memiliki kewenangan dalam penyelenggaraan pemilu.

Terhadap pertanyaan hukum terkait kewenangan KPU dalam membuat peraturan dengan materi muatan didasarkan atas tindak lanjut Putusan Mahkamah Konstitusi Nomor 30/ PUU-XVI/2018. Mahkamah Agung memandang bahwa dalam Pasal 10 ayat (2) UU Nomor 12 Tahun 2011, bahwa tindak lanjut atas putusan Mahkamah Konstitusi dilakukan oleh DPR atau Presiden. Akan tetapi Mahkamah Agung juga menjelaskan bahwa ketentuan tersebut tidak boleh dimaknai sempit, melainkan harus dikaitkan dengan norma hukum lainnya, dan realitas pada saat putusan Mahkamah Konstitusi ditetapkan sehingga diperoleh suatu pemahaman yang komprehensif.

Mahkamah Agung dalam pertimbangannya tidak menafikkan bahwa putusan Mahkamah Konstitusi yang memiliki kekuatan hukum yang tetap sejak selesai diucapkan dalam sidang pleno terbuka untuk umum, sebagaimana diatur dalam Pasal 24C UUD NRI 1945, dan Pasal 47 Undang-Undang Nomor 24 Tahun 2003 tentang Mahkamah Konstitusi.

Mahkamah Agung juga meyakini kewenangan KPU yang menindaklanjuti Putusan Mahkamah Konstitusi Nomor 30/PUUXVI/2018 dengan dibuatnya Peraturan KPU Nomor 26 Tahun 2018 tidaklah bertentangan dengan kewenangan yang dimilikinya. Bahkan Mahkamah Agung melihat juga dalam konvensi ketatanegaraan yang dilakukan kementerian dan lembaga lain dalam menindaklanjuti putusan Mahkamah Konstitusi secara langsung terhitung sejak diucapkan, walaupun tanpa harus menunggu tindak lanjut dari DPR atau Presiden.
Mahkamah Agung kemudian menarik masalah hukum dalam permohonan tersebut, menjadi apakah Peraturan KPU Nomor 26 Tahun 2018 dapat diterapkan pada tahapan pemilu anggota DPD tahun 2019 yang lebih dahulu dilaksanakan. Mahkamah Agung mencoba menjawab pertanyaan tersebut dengan menguraikan tahapan, program, dan jadwal penyelenggaraan pemilu tahun 2019, khususnya menyangkut pencalonan perseorangan peserta pemilu anggota DPD.

Berdasarkan lampiran Peraturan KPU Nomor 7 Tahun 2017 tentang Tahapan, Program dan Jadwal Penyelenggaraan Pemilihan Umum 2019, pendaftaran dan verifikasi calon anggota DPD dimulai tanggal 26 Maret 2018 sampai dengan 8 April 2018, dan diakhiri dengan Pengumuman Daftar Calon Tetap pada tanggal 21 September 2018 sampai dengan tanggal 23 September 2018.

Putusan Mahkamah Konstitusi Nomor 30/ PUU-XVI/2018 diputus pada tanggal 23 Juli 2018, dan pada tanggal 6 Agustus 2018 KPU mengeluarkan Peraturan KPU Nomor 26 Tahun 2018. Pada 1 September 2018 KPU menerbitkan Keputusan KPU tentang Penetapan Daftar Calon Sementara Perseorangan Peserta Pemilu Anggota DPD Tahun 2019, yang menetapkan pemohon sebagai salah satu calon perseorangan peserta pemilu anggota DPD tahun 2019 daerah pemilihan Kalimantan Barat.

Bahwa tanggal 10 September 2018 KPU kembali menerbitkan Keputusan KPU yang berisi kewajiban Bakal Calon Anggota DPD yang merupakan pengurus partai politik tingkat pusat, pengurus partai politik tingkat provinsi, dan pengurus partai politik tingkat kabupaten/ kota untuk mengundurkan diri sebagai pengurus partai politik. 
Bahwa pada tanggal 20 September 2018, KPU menerbitkan Keputusan KPU tentang Penetapan Daftar Calon Tetap Perseorangan Peserta Pemilu Anggota DPD Tahun 2019. Melalui Surat Keputusan ini, termohon dinyatakan tidak memenuhi syarat dan namanya tidak dicantumkan dalam Daftar Calon Tetap, karena pemohon tidak menyerahkan surat pernyataan pengunduran diri sebagai pengurus partai politik ke KPU setempat. Hal ini karena KPU beranggapan bahwa pemohon sudah tidak sesuai dengan peraturan perundang-undangan dan putusan Mahkamah Konstitusi.

Mahkamah Agung kemudian dalam pertimbangannya mendasarkan kepada pemberlakuan surut ketentuan Peraturan KPU Nomor 26 Tahun 2018 terhadap pemohon, dengan dalih pada Peraturan KPU Nomor 14 Tahun 2018 yang mengatur tahapan pencalonan perseorangan peserta pemilu anggota DPD, tidak melarang anggota partai politik untuk mendaftarkan diri sebagai anggota DPD.

Hal tersebut yang kemudian mengakibatkan pemohon merasakan haknya dirugikan, Mahkamah Agung juga kemudian berpikiran bahwa upaya hukum yang dilakukan pemohon adalah wajar dan harus dihormati untuk menegakkan hak-hak asasi yang dijamin UUD NRI 1945. Menyampingkan hak pemohon sebagai warga negara untuk melakukan upaya hukum dalam rangka mencari keadilan dapat dinilai sebagai pengingkaran terhadap hak asasi manusia dan sekaligus tidak menghormati prinsip hukum.

Pendapat Mahkamah Agung demikian tersebut adalah sebuah kesesatan dalam penalaran (fallacy) yang berupa argumentum ad hominem, yaitu menolak atau menerima suatu argumentasi atau usul bukan karena penalaran, tetapi karena keadaan orangnya (Hadjon \& Djatmiati, 2014:1517).

Mahkamah Agung dalam dasar pertimbangan menyatakan bahwa memberlakukan ketentuan dalam Pasal 60A Peraturan KPU Nomor 26 Tahun 2018 adalah penerapan putusan Mahkamah Konstitusi secara retroactive atau surut. Hal tersebut justru menimbulkan ketidakpastian hukum, karena di awal pendapatnya Mahkamah Agung menyatakan bahwa penerapan putusan Mahkamah Konstitusi secara langsung adalah sebuah konvensi ketatanegaraan yang sudah lazim dilakukan. Pada kasus ini, tahapan-tahapan yang dilakukan KPU sudah sesuai dan sesuai dengan Asas-Asas Umum Pemerintahan yang Baik. Pada Pasal 60A Peraturan KPU Nomor 26 Tahun 2018 juga telah memberikan kesempatan bagi calon anggota DPD yang masih menjadi pengurus partai politik untuk mengundurkan diri, hal tersebut yang tidak dijalankan oleh pemohon sebagai sebuah iktikad baik.

Pendapat Mahkamah Agung yang menyatakan bahwa Pasal 60A Peraturan KPU Nomor 26 Tahun 2018 bertentangan dengan ketentuan Pasal 5 huruf d dan Pasal 6 ayat (1) huruf i UU Nomor 12 Tahun 2011, dan tetap mempunyai kekuatan hukum mengikat sepanjang tidak diberlakukan surut terhadap peserta pemilu anggota DPD tahun 2019 yang telah mengikuti tahapan, program dan jadwal penyelenggaran pemilu 2019 berdasarkan Peraturan KPU Nomor 7 Tahun 2017. Hal tersebut menurut Mahkamah Agung dimaksudkan agar adanya kepastian hukum terhadap peserta pemilu anggota DPD tahun 2019, sekaligus untuk menjamin tahapan, program dan jadwal penyelenggaran pemilu 2019 dapat berjalan dengan baik, tidak terganggu oleh 
gugatan dari pihak-pihak yang mengganggap hak-hak hukumnya dirugikan oleh berlakunya Peraturan KPU Nomor 26 Tahun 2018.

Kritik atas Putusan MahakamahAgung yang mendalihkan bahwa Pasal 60A Peraturan KPU Nomor 26 Tahun 2018 bertentangan dengan Pasal 5 huruf d UU Nomor 12 Tahun 2011 yang berarti tidak sesuai dengan "asas dapat dilaksanakan" dalam asas pembentukan peraturan perundangundangan tidaklah tepat. Asas dapat berdasarkan Penjelasan UU Nomor 12 Tahun 2011 dinyatakan bahwa setiap pembentukan peraturan perundangundangan harus memperhitungkan efektivitas peraturan perundang-undangan tersebut di dalam masyarakat, baik secara filosofis, sosiologis, maupun yuridis. Peraturan KPU Nomor 26 Tahun 2018 telah sesuai dengan kondisi secara filosfis, sosiologis, maupun yuridis sebagaimana yang dapat dilihat dalam konsiderannya.

Pasal 60A Peraturan KPU Nomor 26 Tahun 2018 juga dinilai bertentangan dengan Pasal 6 ayat (1) huruf i UU Nomor 12 Tahun 2011 yang berarti tidak sesuai dengan asas ketertiban dan kepastian hukum, yaitu bahwa materi muatan peraturan perundang-undangan harus memperhatikan keragaman penduduk, agama, suku dan golongan, kondisi khusus daerah serta budaya dalam kehidupan bermasyarakat, berbangsa, dan bernegara.

Hal tersebut justru menimbulkan ketidaktertiban dan ketidakpastian hukum pasca diputuskannya Putusan Nomor 65P/HUM/2018. Itu berarti bahwa pengurus (fungsionaris) partai politik tetap dapat mencalonkan diri sebagai anggota DPD pada pemilu 2019, padahal Mahkamah Konstitusi telah menyatakan hal tersebut bertentangan dengan UUD NRI 1945 dan tidak memiliki kekuatan hukum yang mengikat.

\section{B. Putusan Nomor 65P/HUM/2018 Dapatkah Disimpangi oleh Komisi Pemilihan Umum}

Putusan hakim atau putusan pengadilan, atau disebut dengan yurisprudensi merupakan salah satu sumber hukum dari hukum tata negara, apabila putusan tersebut mengenai bidang hukum tata negara (Soehino, 2005:180). Hal ini berarti putusan Mahkamah Konstitusi merupakan salah satu dari sumber hukum hukum tata negara di Indonesia.

Mahkamah Konstitusi adalah salah satu lembaga negara yang memegang kekuasaan kehakiman selain Mahkamah Agung. Fungsi pengadilan yang melekat pada Mahkamah Konstitusi cenderung lebih kepada court of law, daripada court of justice (Huda, 2007:135136). Walaupun demikian tidak dimaknai bahwa Mahkamah Konstitusi tidak menjadikan juctice (keadilan) sebagai tujuan hukumnya, karena jika demikian tidaklah tepat, karena seseorang pergi ke pengadilan tujuan utamanya adalah mendapatkan keadilan sebagaimana tujuan dari hukum itu sendiri. Mahkamah Konstitusi menekankan perlunya keadilan substantif untuk menghindari putusan yang mengabaikan rasa keadilan, hukum yang responsif diperlukan dalam pembentukan maupun penegakan hukum sebagai upaya tercapainya keadilan tersebut.

Kewenangan Mahkamah Konstitusi secara atribusi langsung diberikan oleh UUD NRI 1945, hal tersebut berarti bahwa Mahkamah Konstitusi adalah lembaga negara yang constitutionally entrusted power. Kewenangan Mahkamah Konstitusi disebutkan dalam Pasal 24C UUD NRI 1945, "Mahkamah Konstitusi berwenang mengadili pada tingkat pertama dan terakhir yang putusannya bersifat final untuk menguji 
undang-undang terhadap Undang-Undang Dasar, memutus sengketa kewenangan lembaga negara yang kewenangannya diberikan oleh UndangUndang Dasar, memutus pembubaran partai politik, dan memutus perselisihan tentang hasil pemilihan umum.”

Pada ketentuan tersebut, jelas dinyatakan bahwa putusan Mahkamah Konstitusi bersifat final, yang berarti bahwa sejak dibacakan putusan tersebut dalam sidang pleno, maka putusan tersebut langsung mengikat. Mahkamah Konstitusi dinilai lebih dekat kepada fungsi legislasi daripada peradilan. Karena ketika membatalkan suatu ketentuan undang-undang, pada hakikatnya menciptakan suatu norma baru dengan dihapuskannya norma yang lama (Asshiddiqie, 2007:592). Kelsen (2011: 383) menyebut demikian itu dengan negative legislator yang sangat berbeda dengan fungsi parlemen sebagai positive legislator.

Perkembangan saat ini Mahkamah Konstitusi tidak hanya sebagai negative legislator, akan tetapi Mahkamah Konstitusi dalam putusannya seolah-olah menjadi positive legislator. Hak tersebut dikarenakan kebutuhan untuk menyeimbangkan secara proporsional antara keadilan, kepastian hukum, dan kemanfaatan. Kebutuhan tersebut juga sebagai peran Mahkamah Konstitusi sebagai penyeimbang dan control antara kekuasaan legislatif dan kekuasaan eksekutif. Pembentukan peraturan perundang-undangan di Indonesia diatur dalam Undang-Undang Nomor 12 Tahun 2011 tentang Pembentukan Peraturan Perundangundangan. Secara filosofis pembentukan UU Nomor 12 Tahun 2011 sebagai perwujudan bahwa Indonesia adalah negara hukum, di mana segala aktivitas baik pemerintah maupun warga negara harus sesuai dengan hukum. Sebagai sebuah negara hukum, maka jaminan perlindungan hak dan kewajiban segenap rakyat Indonesia akan dapat terlaksana.

UU Nomor 12 Tahun 2011 memberikan kepastian hukum bagi lembaga yang berwenang membuat peraturan perundang-undangan untuk menghasilkan sebuah produk hukum yang baik. UU Nomor 12 Tahun 2011 juga memastikan pembentukan peraturan perundang-undangan harus dilaksanakan dengan cara dan metode yang pasti, baku, dan standar yang mengikat.

Pembentukan peraturan perundangundangan tidak lepas dari yang namanya hierarki peraturan perundang-undangan, sebagai sebuah konsekuensi penerapan konsep hukum perjenjangan norma. Pasal 7 ayat (1) UU Nomor 12 Tahun 2011 mengatur mengenai hierarki peraturan perundang-undangan di Indonesia, sebagai berikut:

1. Undang-Undang Dasar Negara Republik Indonesia Tahun 1945;

2. Ketetapan Majelis Perwusyawaratan Rakyat;

3. Undang-Undang/Peraturan Pemerintah Pengganti Undang-Undang;

4. Peraturan Pemerintah;

5. Peraturan Presiden;

6. Peraturan Daerah Provinsi; dan

7. Peraturan Daerah kabupaten/ Kota.

Jenis peraturan perundang-undangan yang selain disebutkan dalam Pasal 7 ayat(1)UUNomor 12 Tahun 2011 diatur dalam Pasal 8. Peraturan yang ditetapkan oleh Majelis Permusyawaratan Rakyat, Dewan Perwakilan Daerah, Mahkamah 
Agung, Mahkamah Konstitusi, Badan Pemeriksa Keuangan, Komisi Yudisial, Bank Indonesia, Menteri, badan, lembaga, atau komisi yang setingkat yang dibentuk dengan undang-undang atau pemerintah atas perintah undang-undang, Dewan Perwakilan Rakyat Daerah Provinsi, Gubernur, Dewan Perwakilan Rakyat Daerah Kabupaten/Kota, Bupati/Walikota, Kepala Desa atau yang setingkat. Peraturan yang dibuat oleh lembaga-lembaga tersebut diakui keberadaannya dan mempunyai kekuatan hukum mengikat, sepanjang diperintahkan oleh peraturan perundang-undangan yang lebih tinggi atau dibentuk berdasarkan kewenangan.

UU Nomor 12 Tahun 2011 juga sudah mengakomodir mengenai pengesahan perjanjian internasional tertentu, tindak lanjut atas putusan Mahkamah Konstitusi, dan atau pemenuhan kebutuhan hukum dalam masyarakat, sebagai materi muatan yang harus diatur dalam undangundang. Tindak lanjut atas putusan Mahkamah Konstitusi dilakukan oleh DPR atau Presiden.

Penjelasan UU Nomor 12 Tahun 2011 terkait tindak lanjut atas putusan Mahkamah Konstitusi adalah berkaitan dengan putusan mengenai pengujian undang-undang terhadap UUD NRI 1945. Materi muatan yang dibuat terkait ayat, pasal, dan/atau bagian undangundang yang secara tegas dinyatakan dalam putusan Mahkamah Konstitusi bertentangan dengan UUD NRI 1945. Tindak lanjut atas putusan Mahkamah Konstitusi dimaksudkan untuk mencegah terjadinya kekosongan hukum.

Istilah materi muatan diperkenalkan pertama kali oleh Attamimi (Huda \& Nazriyah, 2011:95), yaitu materi pengaturan yang khas dan semata-mata dimuat dalam undang-undang sehingga menjadi materi muatan undang- undang. Manan (Manan \& Magnar, 1997:145) mengartikan materi muatan adalah muatan yang sesuai dengan bentuk peraturan perundangundangan tertentu.

Kedudukan putusan Mahkamah Konstitusi dalam peraturan perundang-undangan sebagaimana jika mengacu pada UU Nomor 12 Tahun 2011 adalah sebagai materi muatan undang-undang. Sedangkan bagi peraturan perundang-undangan selain undang-undang, kedudukan putusan Mahkamah Konstitusi tidak dapat dijadikan sebagai materi muatan perundang-undangan, karena materi muatan perundang-undangan di bawah undang-undang merupakan peraturan perundang-undangan yang secara hierarki ada di atasnya.

Kedudukan putusan Mahkamah Konstitusi memang diposisikan sebagai check and balances antara kekuasaan legislatif dan kekuasaan eksekutif. Hal itu yang menjadikan alasan bahwa yang dapat menindaklanjuti putusan Mahkamah Konstitusi adalah DPR atau Presiden. Hal tersebut berkaitan dengan kewenangan yang dimiliki oleh dua lembaga tersebut sebagai pembentuk undang-undang.

Putusan Mahkamah Konstitusi terhadap peraturan perundang-undangan di bawah undangundang dapat dijadikan sebagai landasan yuridis dari ratio legis pembentukan peraturan perundangundangan tersebut. Syarat bahwa pembentuk peraturan perundang-undangan adalah lembaga yang berwenang, yang kewenangannya atribusi dari undang-undang. Pendapat ini mengacu pada asas pembentukan peraturan perundang-undangan yang baik, dan asas yang harus tercermin dalam materi muatan peraturan perundang-undangan sebagaimana diatur dalam Pasal 5 dan 6 UU Nomor 12 Tahun 2011. 


\section{KESIMPULAN}

1. Ratio Decidendi hakim dalam Putusan Nomor 65P/HUM/2018 mengalami fallacy yang berupa argumentum ad hominem. Mahkamah Agung lebih mendasarkan kepada kondisi orangnya (pemohon), yang merasakan hak-haknya dirugikan atas dikeluarkannya Peraturan KPU Nomor 26 Tahun 2018 oleh KPU. Padahal Mahkamah Agung sebenarnya telah jelas menyatakan bahwa secara substansi Peraturan KPU Nomor 26 Tahun 2018 telah sesuai dengan konvensi ketatanegaraan tentang menindaklanjuti atas adanya putusan Mahkamah Konstitusi.

2. Putusan Nomor 65P/HUM/2018 dapat disimpangi oleh KPU terhadap calon anggota DPD yang masih terdaftar sebagai pengurus (fungsionaris) partai politik. Dasar hukum yang dijadikan acuan penyimpangan adalah Putusan Mahkamah Konstitusi Nomor 30/PUU-XVI/2018.

\section{SARAN}

1. Seyogianya dilakukan eksaminasi terhadap Putusan Nomor 65P/HUM/2018 untuk menciptakan suatu kepastian hukum tentang pencalonan anggota DPD yang juga berasal dari pengurus (fungsionaris) partai politik.

2. Seyogianya pejabat yang berwenang (DPR atau Presiden) lebih responsif terhadap putusan Mahkamah Konstitusi yang berkaitan dengan pengujian undangundang terhadap UUD NRI 1945, bahwa undang-undang tersebut telah dinyatakan bertentangan dengan UUD NRI 1945 dan tidak memiliki kekuatan hukum yang mengikat. Karena secara teoritis DPR atau Presiden adalah lembaga yang memiliki kewenangan untuk melaksanakan putusan Mahkamah Konstitusi mengenai perbaikan materi muatan dalam undang-undang

\section{DAFTAR ACUAN}

\section{Buku}

Asshiddiqie, J. (2007). Pokok-pokok hukum tata negara Indonesia pasca reformasi. Jakarta: PT Bhuana Ilmu Populer. . (2010). Perihal undang-undang. Jakarta: PT Rajagrafindo Persada.

Hadjon, P.M. \& Djatmiati, T.S. (2014). Argumentasi hukum: Langkah-langkah legal problem solving \& penyusunan legal opinion. Yogyakarta: Gadjah Mada University Press.

Huda, N. \& Nazriyah, R. (2011). Teori \& pengujian peraturan perundang-undangan. Bandung: Nusa Media.

Huda, N. (2007). Lembaga negara dalam masa transisi demokrasi. Yogyakarta: UII Press.

Kelsen, H. (2011). Teori umum tentang hukum dan negara. Bandung: Nusamedia dan Nuansa. Diterjemahkan oleh Raisul Muttaqien dari Hans Kelsen. (1971). General Theory of Law and State. New York: Russel and Russel.

Manan, B. \& Magnar, K. (1997). Beberapa masalah hukum tata negara Indonesia. Bandung: Alumni.

Martitah. (2013). Mahkamah Konstitusi dari negative legislature ke positive legislature. Jakarta: Konstitusi Press. 
Safa'at, M.A. (2010). Parlemen bikameral (Studi perbandingan di Amerika Serikat, Prancis, Belanda, Inggris, Austria, \& Indonesia). Malang: UB Press.

Sirajuddin \& Winardi. (2015). Dasar-dasar hukum tata negara Indonesia. Malang: Setara Press.

Soehino. (2005). Hukum tata negara: Sumber-sumber hukum tata negara Indonesia. Yogyakarta: Liberty Yogyakarta.

\section{$\underline{\text { Jurnal }}$}

Marzuki, H.M.L. (2007, Juni). Membangun undangundang yang ideal. Jurnal Legislasi Indonesia, $4(2), 1-6$.

Mas, M. (2012). Penguatan argumentasi fakta-fakta persidangan \& teori hukum dalam putusan hakim (Kajian Putusan Nomor 181 K/Pid/2007/ MA). Jurnal Yudisial, 5(3), 283-297.

Sambuari, F.P. (2013, April-Juni). Eksistensi putusan judicial review oleh Mahkamah Konstitusi. Jurnal Lex Administratum, 1(2), 17-24.

Sulardi \& Wardoyo, Y.P. (2015, Desember). Kepastian hukum, kemanfaatan, \& keadilan terhadap perkara pidana anak (Kajian Putusan Nomor 201/Pid.Sus/2014/PN.Btl). Jurnal Yudisial, $8(3), 251-268$.

Tinambunan, H.S.R. \& Prasetio, D.E. (2019, Juli). Rekontruksi Konstitusi dalam regional representative Dewan Perwakilan Daerah terhadap fungsi legislatif. Jurnal MasalahMasalah Hukum, 48(3), 266-274.

Weruin, U.U. (2017). Logika, penalaran, \& argumentasi hukum. Jurnal Konstitusi, 14(2), 374-395.

\section{$\underline{\text { Sumber lainnya }}$}

Isra, S. (2010). Negative legislator. Diakses dari https://www.saldiisra.web.id/index.php/21makalah/makalah1/302-negative-legislator.html.

Syafa'at, A. (2018). Kekuatan mengikat \& pelaksanaan putusan MK. Diakses dari http:// safaat.lecture.ub.ac.id/files/2014/03/KekuatanMengikat-dan-Pelaksanaan-Putusan-MK.pdf. 